\title{
Illegal Loves and Sexual Deviancy: Homosexuality as a Threat in Cold War Canada
}

\author{
Erin Gallagher-Cohoon
}

This paper analyzes the criminalization and medicalization of homosexuality during the early twentieth century in Canada. Through court records and medical texts the discourse of homosexuality as a threat to the family unit and to the nation is contextualized within Cold War rhetoric. A Foucaultian conceptualization of power and discipline helps frame questions regarding homosexuality as a criminal offense and as a mental illness. It is argued that both state control and societal pressures constructed the homosexual as criminal, the homosexual as mental patient and, as a result, the homosexual as Communist threat.

On the 15th of December, 1947, three personal letters were entered as evidence in the court case of James A. Hall, who was accused of "unlawfully commit[ting] an act of gross indecency." In one, the accused wrote, "“Thank you' again for everything, mostly for your love -your consideration and the honor of being able to call you 'my own." The only feature that made this private declaration of love a matter of state intervention was that Hall's lover was another man, Charles Orton. Both men, in their testimony, blamed the other as the sexual aggressor. This contrasts the affectionate and occasionally erotic tone of their private correspondence. Hall pleaded guilty and was sentenced to nine months of imprisonment. Orton, for his part, reappeared several times in the court records as both witness and defendant. ${ }^{1}$ But how did a moment of private eroticism become a matter of criminal importance?

While court records provide an entry point into the criminalization of male homosexuality during the Cold War era in Canada, the discourse and rhetoric surrounding this marginalized group are also seen in psychiatric and other mental health texts. It is important to note the specification of "male homosexuality" as many of the sources available deal exclusively with men. Also, male homosexuals were perceived, by the state apparatus, as particularly threatening. As a result, this paper will examine the experiences of men as homosexuals. Using a model based on the philosopher Michel Foucault's theory of the disciplinary creation of normality, this paper will analyze how the criminalization and medicalization of homosexuality as "abnormal" and "deviant" contributed to Cold War fears of the threatening "Other." 2 Primary sources such as Supreme Court cases, newspaper articles, Sigmund Freud's essays and the oft-mentioned Kinsey report describe the dark side of normalization techniques used by both the state and society more generally.

These primary sources can be used to access both the voices of homosexual men, or at the very least, men accused of homosexual acts, and the larger superstructure of control. Historians have already used these and other records to address issues of social perceptions of sexual deviancy and to uncover discriminatory practices, especially within the civil service,

\footnotetext{
${ }^{1}$ PAA, 83.1/7240 (New Series), gross indecency, 1947.

${ }^{2}$ Michel Foucault, Security, Territory, Population: Lectures at the Collège de France, 1977-1978, trans. Graham Burchell (New York: Palgrave Macmillan, 2007), 57.
} 
towards those who were ousted as "deviants." Gary Kinsman and Patrizia Gentile, for example, co-authored a book entitled The Canadian War on Queers. Kinsman, a professor of sociology at Laurentian University and a gay activist, writes extensively on the antihomosexual security campaign during the Cold War period. ${ }^{3}$ The Canadian War on Queers, for example, uses interviews and governmental records to reconstruct the national security regime and its conceptualization of homosexuality and gender inversion as threats. While there is a blatantly political tone that is sustained throughout the book because of the link it makes between the Cold War period and present day security techniques, this is a vitally important secondary source on the widespread discrimination against homosexuals. ${ }^{4}$

Other scholars, whether historians, political scientists or sociologists, are equally intrigued by the development of state security vetting, especially in the creation of the "Fruit Machine," which was an experimental device aimed at detecting homosexuals. ${ }^{5}$ However, there is another area of study that is vital to understanding the larger societal mechanisms in place that positioned homosexuality as threatening. Scholars such as Mary Louise Adams and Michael Warner discuss the normalization of certain sexual expressions as opposed to their "abnormal" counterparts. In The Trouble with Normal: Postwar Youth and the Making of Heterosexuality, Adams conceptualizes heterosexuality in relation to the imposition of norms on the youth. ${ }^{6}$ Approaching the question from a different direction, Warner's similarly titled book, The Trouble with Normal: Sex, Politics, and the Ethics of Queer Life, though neither based on a Canadian context, nor directly historical, provides a good framework for understanding North American cultural norms. Warner is especially interested in the politics of sexual shame and the mutability of sexual norms. ${ }^{7}$

From the perspective of societal pressures and the normalization of heterosexuality, Adams and Warner provide important context related to the creation of a homosexual "Other." Within both of their work, it is possible to see what Foucault terms "disciplinary normalization." Foucault describes this term as "trying to get people, movements, and actions to conform... the normal being precisely that which can conform to this norm, and the abnormal that which is incapable of conforming." ${ }^{8}$ But how does the state machinery deal with the non-conforming abnormal, especially in times of great stress and international fear such as the Cold War? And how did it categorize those who were outside the boundaries of "normal"?

Homosexuality,

\footnotetext{
${ }^{3}$ Matthew Burrows, "Gary Kinsman's Book Canadian War on Queers Takes on Gay Issues in Government," Georgia Straight (Vancouver, BC), March 18, 2010, http://www.straight.com/article-298209/vancouver/booktakes-gay-issues-government.

${ }^{4}$ Gary Kinsman and Patrizia Gentile, The Canadian War on Queers (Vancouver: The University of British Columbia, 2012).

${ }^{5}$ Daniel J. Robinson and David Kimmel, "The Queer Career of Homosexual Security Vetting in Cold War Canada," Canadian Historical Review 75, no.3 (September 1994): 320. See also Gary Kinsman, " 'Character Weaknesses' and 'Fruit Machines': Towards an Analysis of the Anti-Homosexual Security Campaign in the Canadian Civil Service, 1959-1964," in Crime and Deviance in Canada: Historical Perspectives, ed. Chris McCormick and Len Green (Toronto: Canadian Scholars' Press, 2005), 322-333.

${ }^{6}$ Mary Louise Adams, The Trouble with Normal: Postwar Youth and the Making of Heterosexuality (Toronto: University of Toronto Press, 1997).

${ }^{7}$ Michael Warner, The Trouble with Normal: Sex, Politics and the Ethics of Queer Life (Cambridge, Massachusetts: Harvard University Press, 1999).

${ }^{8}$ Foucault, Security, Territory, Population, 57.
} 
as historian Elise Chenier perceives it, is a sub-category of "sexual deviants," a term constructed in the postwar era which also included pedophiles and exhibitionists. Though taking pains to separate the divergent categories of pedophilia and homosexuality (two groups that have often been conflated in conservative rhetoric), Chenier deals with the treatment and criminalization of sexual deviants as a group. She relates this to larger fears regarding the moral and physical safety of youth and the construction of ideas about sex offenders. ${ }^{9}$ Historians and other scholars that deal with the Cold War in Canada, through topics such as the valorization of the nuclear family or the demonization of deviant sexuality, are a key reminder of the context that gave rise to the extensive RCMP surveillance of suspected homosexuals. After the defection of the Soviet clerk Igor Gouzenko in 1945, Canadian policymakers were worried about his claims that a wide-ranging spy ring was operating in Canada, not only through known Communists, but also through civil servants and intellectuals. Not surprisingly, Communist spies were seen as the newest threat to Canadian democracy, a sentiment that was encouraged by American policymakers. ${ }^{10}$ Though they were typically more circumspect than their McCarthyite counterparts, the Canadian civil service did in fact inaugurate an intensive search for political subversives within its ranks. But how and why did the RCMP begin to investigate those deemed to have "character weaknesses"?

Partly explained by fears that civil servants were leaving themselves open to blackmail, this turn from targeting political subversives to targeting sexual subversives can also be explained by examining assumptions about homosexuality. Homosexuality was framed as a danger to both the state and the family during an era of increased fear of sexual predation. Chenier notes that "the sex offender is a construction: grounded in pre-Second World War studies of homosexuality, tainted as they were by midcentury heterosexist ideas about what constituted maturity and normalcy, and what constituted danger and harm." ${ }^{11}$ Even the terminology surrounding it encouraged a sense of fear. It was described, for example, as "sexual psychopathy." 12

This construction of homosexuality as a sexual, social, and political danger is an important component of Cold War rhetoric, but is not unique to the Cold War period. As Julian Lee argues in his political account of how states police sexuality, all societies structure sexual behaviour according to their interests. ${ }^{13}$ Warner also remarks on the stigmatization of certain segments of the population, outside the Cold War era, because of so-called "deviant" or "criminal" sexual choices. ${ }^{14}$ The Cold War era was unique, however, because of the confluence of homosexuality with Communism. Within the unique context of the Cold War, the discourse about homosexuality as a sexual threat was transferred to a discourse of homosexuality as a national security concern. This was done through two main disciplinary devices, criminalization and medicalization.

\footnotetext{
${ }^{9}$ Elise Chenier, Strangers in Our Midst: Sexual Deviancy in Postwar Ontario (Toronto: University of Toronto Press, 2008). For a discussion on intergenerational sex, pedophilia and homosexuality, see Steven Maynard, "The Maple Leaf (Gardens) Forever: Sex, Canadian Historians and National History," Journal of Canadian Studies 36, no. 2 (Summer 2001): 71-88.

${ }^{10}$ See, for example, Amy Knight, How the Cold War Began: The Igor Gouzenko Affair and the Hunt for Soviet Spies (New York: Carroll \& Graf Publishers, 2005).

${ }^{11}$ Chenier, Strangers in Our Midst, 113.

12 Kinsman, " 'Character Weaknesses'," 143.

${ }^{13}$ Julian C.H. Lee, Policing Sexuality: Sex, Society, and the State (London: Zed Books, 2011), 27.

${ }^{14}$ Warner, The Trouble with Normal, 11, 28-29.
} 
State officials used paradoxical reasoning to justify the criminalization of homosexuality. According to this argument, homosexual acts were criminal. This left homosexuals open to harassment by the state, and blackmail by an enemy nation. Because they could be blackmailed and were a possible security risk, and because they refused to conform to Cold War norms, homosexuality was not only deviant but also criminal.

As one particular case study can demonstrate, the "criminal homosexual" was clearly linked to military and governmental hierarchies, or so it was feared. Leo Mantha, the last person to be hung in British Columbia, murdered his estranged lover, Aaron Jenkins, on September 6, 1958. They were both members of the Royal Canadian Navy and had become involved in the summer of 1958. Jenkins was stabbed and killed after he tried to break up with Mantha. Relying on contemporary psychiatric assumptions about homosexuality as a mental illness, Mantha's defence would nonetheless fail to have his execution commuted. While Kinsman and Gentile see this pivotal case as one of the catalysts of the widespread RCMP investigation into homosexuals, it is equally interesting because it demonstrates the intersection between the criminalization and medicalization of homosexuality. ${ }^{15}$

Medical notions about the mental abnormality of homosexuals were extremely influential, and issues of gender norms played into this. Homosexuals were condemned for supposedly inverting the stability of gendered relations. A homosexual male was thought to have the same negatively "feminine" characteristics that women were said to have: weakness, a tendency to compromise, and passivity. It was argued that they lacked the moral strength necessary to resist the seditious rhetoric of Communism. ${ }^{16}$ Interestingly, this contradicts the image of homosexual men as sexual predators who, like Communist spies, would infiltrate and taint the morals of vulnerable youth.

This dichotomy is glimpsed in court records as men accused of "gross indecency" with other men would often frame their testimony in certain ways depending on how it would benefit them. In one case, for example, John Gawlicki admitted that Charles Orton "took my peanus [sic] in his mouth and sucked me off. He then wanted me to do the same thing to him, but I refused... Charlie again took my peanus [sic] in his mouth and attempted to suck me off again, but I didn't let him finish." ${ }^{17}$ In this account, Gawlicki took the active role by remaining the penetrator and by controlling the action; Charlie was relegated to the passive role of a "true" homosexual.

Using a different tactic, James A. Hall, who was mentioned at the beginning of this paper, provides an interesting contrast. Both Hall and Orton attempted to blame the other as the sexual aggressor. In Orton's testimony, "Mr. Hall began to play around with my privates." This act led to oral sex, which Hall was once again accused of initiating. Hall's statement, however, provided a mirror opposite account with "Charlie [starting] to play around with [his] privates" and then initiating oral sex. ${ }^{18}$ Though it is impossible for historians to discover what truthfully happened that night in the hotel room between the two men, what is noteworthy is their mutual accusations and the way it positions the "true" homosexual as the aggressor, not the "femininely" passive victim.

\footnotetext{
${ }^{15}$ Kinsman, The Canadian War, 97-101.

${ }^{16}$ Adams, Trouble with Normal, 23.

${ }^{17}$ PAA, 83.1/7132 (New Series), gross indecency, 1947.

${ }^{18}$ PAA, 83.1/7240 (New Series), gross indecency, 1947.
} 
Within these two accounts of criminal homosexuality, Charles Orton appeared as a witness whose testimony would no doubt be incidental in condemning his lovers. A case involving Fred Brunn would also bring Orton to the witness stand, though at that time he was serving seven years in the Fort Saskatchewan Gaol after his own day in court. ${ }^{19}$ Orton's role in numerous cases between 1946 and 1947 raises questions regarding the nature of his relationship to the police. It is acknowledged by historians that the RCMP used informers to convict homosexuals and that the testimony of known homosexuals was one of their only methods of uncovering this so-called criminal element. ${ }^{20}$

Charles Orton himself was eventually convicted with three counts of gross indecency and one count of promoting or contributing to a child becoming a juvenile delinquent. Though the record is sparse, it can be inferred that the child in question, Nick Stefanick, was a relation to one of the men Orton was accused of having a relationship with, Steve Stefanik. This brings back the spectre of pedophilia and the threat of homosexuality to the family unit. Homosexuality, was not only a criminal act, but was also seen as a corrupting influence. $^{21}$

Court records also point to the tabooed nature of homosexuality. In fact, the word "homosexual" is never used in the Supreme Court of Alberta cases looked at. No man is charged with homosexual acts, but rather, with "unlawfully [committing] an act of gross indecency with another male person." The earlier use of the term "buggery" is also absent in these cases. One record in particular stands out. Allan Shaw was accused in 1944 of gross indecency with Yves Hurtubise. Unlike the previous cases, there is no indication that this was a mutual relationship accidentally discovered by state powers. Hurtubise and another air force pilot spent the night at the house of the accused and, though strangers, supposedly thought nothing of his friendly touches or even the plaster cast of his genitals that he showed them. However, when Hurtubise found himself naked in bed with Shaw, "[he] put his - he said - he put his penis between my legs or somewhere, and I push [sic] him over. I said, 'I am not that kind of a guy'." ${ }^{22}$ Similar hesitation and uncertainty marked the rest of Hurtubise's testimony and hinted at society's discomfort with homosexual acts.

This discomfort is plain to see in the mental health structure as well. ${ }^{23}$ Psychotherapy, as espoused by Freud, regarded homosexuality as an inversion and a retardation of sexual maturity. Consequently, homosexuality was linked to gender inversion. Although Freud denied that it was a "universal characteristic of inversion," he did uphold that many inverts are "like a woman in being subject to the charm that proceeds from masculine attributes both physical and mental." ${ }^{24}$ In essence, as already seen, some believed that a "real" homosexual was only the male who was sexually passive, whereas his dominant male partner could still be portrayed as a "real" man. This dichotomy between

\footnotetext{
${ }^{19}$ PAA, $83.1 / 7130$ (New Series), gross indecency, 1946.

${ }^{20}$ Kinsman, The Canadian War on Queers, 2-3.

${ }^{21}$ PAA, 83.1/7399 (New Series), gross indecency, 1947.

${ }^{22}$ PAA, 83.1/4712 (New Series), gross indecency, 1944.

${ }^{23}$ For a discussion on the evolution of psychoanalytic theories regarding homosexuality, see Jack Drescher, "A History of Homosexuality and Organized Psychoanalysis," Journal of the American Academy of Psychoanalysis and Dynamic Psychiatry 36, no 3 (Fall 2008): 443-460.

${ }^{24}$ Sigmund Freud, "The Sexual Aberrations," in Three Essays on the Theory of Sexuality, trans. and ed. James Strachey (New York: Basic Books, 2000), 10.
} 
homosexuality and masculinity is also seen in Martin Duberman's autobiography. Cures: $A$ Gay Man's Odyssey describes his attempt to cure his homosexuality during the Cold War years in the United States of America. He stated, for example, "A "real man," as we all knew in those years (and as many continue to affirm), was unyieldingly dominant, the penetrator, the aggressor, someone who took only the active role in bed." ${ }^{25}$ This conceptualization of the active man in opposition to the effeminate homosexual is also described in Chenier's analysis of homosexuality in prisons and, as we've already seen, is supported by court records. ${ }^{26}$

Duberman's autobiography shows that the rise of the medical establishment and twentieth-century faith in scientific cures fed into already present beliefs about the abnormality of homosexuality. Though based in the United States, this book remains a good personal account of the mental space inhabited by many homosexuals who hoped to be cured of their "disease." Many turned, in the 1950s culture of therapy, to psychiatrists and psychotherapists as their saviours. Duberman described his belief in his therapists and their claims that he could make a "heterosexual adjustment" by "unblock[ing]" his "heterosexual yearnings." 27 It is obvious that the goal was not personal acceptance but rather personal rejection. This account shows that it was believed, by at least one segment of the medical community, that homosexuality was a learned behaviour that could be unlearned.

This goes back to Freudian theories regarding the sexual immaturity of homosexuals. It was seen as a failure of the Oedipus complex because, during a healthy adjustment, men would be deterred from their own gender by their father's rejection and competition with them. Homosexuality, described as an inversion of object-choice, was a result of stunted growth and a reversal to infantile sexuality. If normal growth could be resumed, it was believed that a homosexual could be cured of his deviant object-choice. ${ }^{28}$ Though the mental health field is far from a monolith, before the mid 1960s, the majority of psychiatrists "rigidly viewed homosexuality as a psychological disturbance that combined an inner masochistic tendency with a psycho-adaptational fear of the opposite sex." ${ }^{29}$ This disregard for homosexuality as a valid sexual preference often went further than some of Freud's ideas. Despite his description of homosexuality as a sexual retardation, Freud still posited that sexual inversion was found in individuals who did not have any other mental problems. In other words, homosexuality did not necessarily imply psychosis or neurosis. ${ }^{30}$

In contrast to the position held by most of the psychotherapeutic community, the sexologist Alfred Kinsey provided an alternative view of homosexuality. The Kinsey report was revolutionary because of its views of sexuality, but especially because it normalized homosexuality as a not inconsequential position on a spectrum of sexual preferences. Using a quantitative analysis of a large number of case studies, Sexual Behavior in the Human Male

\footnotetext{
${ }^{25}$ Martin Duberman, Cures: A Gay Man's Odyssey (Boulder, Colorado: Westview Press, 2002), 25.

${ }^{26}$ Chenier, Strangers in Our Midst, 174.

${ }^{27}$ Duberman, Cures, 94.

${ }^{28}$ Freud, "Transformation of Puberty," in Three Essays on the Theory of Sexuality, trans. and ed. James Strachey (New York: Basic Books, 2000), 95.

${ }^{29}$ Howard Hsueh-Hao Chiang, "Effecting Science, Affection Medicine: Homosexuality, The Kinsey Reports, and the Contested Boundaries of Psychopathology in the United States, 1948-1965," Journal of the History of the Behavioral Sciences 44, no. 4 (Fall 2008): 301.

${ }^{30}$ Drescher, "A History of Homosexuality," 445.
} 
controversially made declarations such as "perhaps the major portion of the male population, has at least some homosexual experience between adolescence and old age." ${ }^{31}$ The numbers themselves lead Kinsey to question the common assertion that homosexuality is "evidence of neuroses or even psychoses." ${ }^{32}$

Despite this revisionist view of sexuality, the general consensus remained that homosexuality was abnormal and, if possible, needed to be cured. Though not a commonly broached subject, newspaper articles in the Globe and Mail and the Toronto Daily Star pointed to common perceptions of homosexuality. Films and plays were censored for homosexual material, a tendency also examined by Adams in her discussion of the criminalization of lesbian literature as obscenity. ${ }^{33}$ Other articles described homosexuality as sexual immaturity and encouraged psychiatric care over imprisonment which "would not cure sexual deviation." 34 Reports of court cases in the press noted the abnormality and emotional instability of homosexuals. ${ }^{35}$ Newspapers provided insight into not only popular opinions of homosexuality but also the debates experts engaged in over the implications of psychiatry and crime in relation to homosexual acts.

Other authors have also noticed this push towards curing homosexuality, a tendency that was often adjacent to attempts to protect society by isolating or imprisoning those deemed to be sexually deviant. Chenier notes that psychotherapy was often used alongside shock therapy, drugs, and the use of appropriate role models of masculinity to teach homosexuals to become heterosexual. ${ }^{36}$ Some therapists hoped only to train men to not commit homosexual acts, in the hopes that they would uphold the ideal nuclear family through the presentation of marriage and heterosexuality. Other medical experts were convinced "that homosexuals were pathological in their very being, whether they ever committed an immoral act or not, simply by the nature of their desires." ${ }^{37}$ As Duberman noted, the very creation of a dichotomy between normal and abnormal desires, bolstered by techniques commonly used in therapy, further denigrated an already marginalized group and contributed to individuals' feelings of self-hatred. ${ }^{38}$ The irony of the therapeutic cure of homosexuality is that, rather than aid the people they were supposed to help adjust, they often increased their likelihood of depression, addiction or other mental illnesses.

The federal government itself supported psychiatric understandings of homosexuality as a "disorder" by encouraging research into the "Fruit Machine." The Fruit Machine was an attempt to scientifically detect homosexuals within the civil service. Between

\footnotetext{
${ }^{31}$ Alfred C. Kinsey, Wardell B. Pomeroy and Clyde E. Martin, Sexual Behavior in the Human Male (London: W.B. Saunders Company,1948), 610.

32 Ibid., 659 .

33 See, for example, "Britain's Censor of Plays Comes in for Censure," Globe and Mail, April 12, 1958; "Violent U.S. Movies Offend Britons," Globe and Mail, October 15, 1960; Mary Louise Adams, "Margin Notes: Reading Lesbianism as Obscenity in a Cold War Courtroom," in Love, Hate, and Fear in Canada's Cold War, ed. Richard Cavell (Toronto: University of Toronto Press, 2004), 135-158.

34 "Doctor Says Horror, Fear of Homosexuality Block Achieving Sexual Maturity," Globe and Mail, February 6, 1961.

35 "Barrie Mind Concealed Purpose, But What? - Hope," Toronto Daily Star, June 26, 1947.

${ }^{36}$ Chenier, Strangers in Our Midst, 155.

${ }^{37}$ Warner, Trouble with Normal, 28.

${ }^{38}$ Duberman, Cures, 171.
} 
1962 and 1967, Dr. F.R. Wake researched a battery of tests that were supposed to identify homosexual individuals. These included the Hess-Polt pupillary test, which would measure pupil dilation in response to visually erotic stimuli, the Masculinity/Femininity Test, and the Palmer Sweat test. ${ }^{39}$ It was never put into practice because there were too many problems related to its implementation. Key among these was the lack of scientific proof that it detected homosexuals with any reliability. Despite this, it is an example that underscores both the seriousness of the "homosexual threat" to officials and their reliance on psychiatry in their understandings of what made a homosexual.

While both the medical institution and the criminal justice system positioned homosexuals as essentially abnormal and in need of either reform or disciplinary action, homosexuality was not only seen as a threat of importance on the level of the state but also as a danger to individual families. The return to the family and the emphasis on the vulnerability of youth are oft-noted characteristics of the postwar era. Adams remarks that "the ideal family was at once seen as a source of affectional relationships, the basis of a consumer economy, a defence against Communism, and a salient metaphor for various forms of social organization, from the nation to the high-school class." ${ }^{40}$ The dark side of this was anything, homosexuality included, that was thought to threaten the family with disintegration.

In response, some homosexual men attempted to pass by marrying and raising families. Duberman wrote that he "had known other gay men who had married, who had functioned well enough sexually to have children, and who had seemed content. Their strategies for dealing with homosexual urges varied from secret trips to the baths to celibacy (extending, after a while, even to their wives)." ${ }^{41}$ Though certainly not a sign of mental health and happiness, repression of their sexual desires remained for many a key survival technique in a society that viewed them as destructive.

Fears about homosexuality as detrimental to the family and, especially, about the moral vulnerability of youth to sexual predation continued even after Cold War fears began to die down. In 1977, for example, when the Ontario Human Rights Commission recommended protections against discrimination because of sexual orientation, Toronto became a hub of homophobic attitudes. Suspicions of the possibility of homosexual teachers inculcating children were interrelated to fears of homosexual predators. ${ }^{42}$

Within the larger context of the state, homosexuality was seen as equally menacing. Adams sees in this "the displacement of general social and political anxieties," but this does not completely explain political fears of alternative sexualities. ${ }^{43}$ Homosexuality was not only a cause for blackmail but also a "character weakness," in the rhetoric of the day. Though character weaknesses applied to any number of situations, even those that imply hypermasculinity such as a man who engages in extra-marital affairs, in the late 1950s, it came to be used mainly for homosexuals. ${ }^{44}$ They were seen as lacking emotional stability and

\footnotetext{
${ }^{39}$ Kinsman, " 'Character Weaknesses'," 156-157.

${ }^{40}$ Adams, Trouble with Normal, 20.

${ }^{41}$ Duberman, Cures, 59.

${ }^{42}$ Michael Graydon, " 'Kids Not Rights, is Their Craving': Sex Education, Gay Rights, and the Threat of Gay Teachers," Canadian Review of Sociology 48, no. 3 (August 2011): 313-314.

${ }^{43}$ Adams, Trouble with Normal, 24.

${ }^{44}$ Kinsman, The Canadian War, 86-87.
} 
maturity, having a weak moral fibre and being overly interested in seducing colleagues rather than serving their country. ${ }^{45}$ It was also feared that if a person could hide such an integral part of their mental landscape, even potentially to flaunt convention and law by their actions, they could be operating undercover as a Communist as well. ${ }^{46}$ As late as 1977, Donal MacNamara and Edward Sagarin wrote that "[i]llegal, stigmatized, and concealed behavior lends itself to concomitant crime. This is true of homosexuality at least as much as it is of prostitution." ${ }^{47}$ As a result of these fears and the security campaigns put into place to address them, hundreds of homosexuals either lost their jobs within the civil service or were transferred to positions considered to be less sensitive. ${ }^{48}$

Though views on a supposed homosexual personality type have been shown to be untrue, there were some links between the early gay movement and left-wing politics. This is simply another added layer to the political elites' justification of their persecution of homosexuals. In the United States, for example, the Mattachine Society, a homophile organization, was initially founded by activists who also took part in the labour movement. But by 1953, Cold War fears led to a de-radicalization of the Mattachine. ${ }^{49}$ British spy scandals also linked homosexuality to Communist spying as, most notably, several members of the Cambridge Five happened to be gay. ${ }^{50}$ These links only affirmed, in the public's, the politician's and the RCMP's minds, that homosexuality was a very real threat to national security and that homosexuals were more prone to being Communist-sympathizers.

While homosexuals were seen as threatening to both the state body and the family unit, the effects of such fear were not only felt within the civil service or within individual families. Rather, the larger persecution against homosexuals can be gleamed through court records and mental health texts. A Foucaultian conceptualization of power and discipline helps frame questions regarding the discourse of homosexuality as a criminal offense and as a mental illness. Court records demonstrate, sometimes in the men's own words, what actions and reactions were considered homosexual. As seen, this is linked to conceptions of gender inversion. And though the courts tended to eroticize homosexual relationships as somewhat sleazy encounters in hotel rooms, there is also an occasional hint at genuine emotion. This is found, not in the bitter or uncomfortable testimony supplied to the court, but rather in the evidence such as personal letters. It is in those lucky finds that homosexual couples may be encountered in brief moments of time. In contrast, mental health texts and newspaper articles provide a perspective from the experts of the day as they tried to understand what created homosexual desires and how to control them. It is in the process of surveillance and control that Foucault's 'disciplinary normalization' is mainly seen. In essence, not only state control, but also societal pressures created the homosexual as criminal, the homosexual as mental patient, and, as a result, the homosexual as Communist threat.

\footnotetext{
${ }^{45}$ Duberman, Cures, 47; Adams, Trouble with Normal, 23.

${ }^{46}$ Lee, Policing Sexuality, 84.

${ }^{47}$ Donal E.J. MacNamara and Edward Sagarin, Sex, Crime, and the Law (New York: The Free Press, 1977$), 156$.

${ }^{48}$ Kinsman, " 'Character Weaknesses'," 322

${ }^{49}$ Warner, Trouble with Normal, 46.

${ }^{50}$ Kinsman, " 'Character Weaknesses'," 138.
} 


\section{Bibliography}

Adams, Mary Louise. "Margin Notes: Reading Lesbianism as Obscenity in a Cold War Courtroom." In Love, Hate, and Fear in Canada's Cold War, edited by Richard Cavell, 135-158. Toronto: University of Toronto Press, 2004.

-. The Trouble with Normal: Postwar Youth and the Making of Herterosexuality. Toronto: University of Toronto Press, 1997.

Burrows, Matthew. "Gary Kinsman's Book Canadian War on Queers Takes on Gay Issues in Government." Straight.com, March 18, $2010 . \quad$ http://www.straight.com/article298209/vancouver/book-takes-gay-issues- government.

Chenier, Elise. Strangers in Our Midst: Sexual Deviancy in Postwar Ontario. Toronto: University of Toronto Press, 2008.

Chiang, Howard Hsueh-Hao. "Effecting Science, Affection Medicine: Homosexuality, The Kinsey Reports, and the Contested Boundaries of Psychopathology in the United States, 1948-1965." Journal of the History of the Behavioral Sciences 44, no. 4 (Fall 2008): 300-318

Duberman, Martin. Cures: A Gay Man's Odyssey. Boulder, Colorado: Westview Press, 2002.

Drescher, Jack. "A History of Homosexuality and Organized Psychoanalysis." Journal of the American Academy of Psychoanalysis and Dynamic Psychiatry 36, no 3 (Fall 2008): 443-460.

Foucault, Michel. Security, Territory, Population: Lectures at the Collège de France, 1977-1978, translated by Graham Burchell. New York: Palgrave MacMillan, 2007.

Freud, Sigmund. Deviant Love, translated by Shaun Whiteside. London: Penguin Books, 2006.

Freud, Sigmund. "The Sexual Aberrations." In Three Essays on the Theory of Sexuality, translated and edited by James Strachey, 1-38. New York: Basic Books, 2000.

Freud, Sigmund. "The Transformations of Puberty." In Three Essays on the Theory of Sexuality, translated and edited by James Strachey, 73-96. New York: Basic Books, 2000.

Kinsey, Alfred C., Wardell B. Pomeroy, and Clyde E. Martin. Sexual Behavior in the Human Male. London: W.B. Saunders Company, 1948.

Kinsman, Gary. " 'Character Weaknesses' and 'Fruit Machines': Towards an Analysis of the AntiHomosexual Security Campaign in the Canadian Civil Service, 1959- $\quad$ 1964." In Crime and Deviance in Canada: Historical Perspectives, edited by Chris McCormick and Len Green, 322-333. Toronto: Canadian Scholars' Press, 2005.

Kinsman, Gary, and Patrizia Gentile. The Canadian War on Queers. Vancouver: The University of British Columbia, 2010.

Lee, Julian C.H. Policing Sexuality: Sex, Society, and the State. London: Zed Books, 2011.

MacNamara, Donal E.J., and Edward Sagarin. Sex, Crime, and the Law. New York: The Free Press, 1977.

Maynard, Steven. "The Maple Leaf (Gardens) Forever: Sex, Canadian Historians and $\quad$ National History." Journal of Canadian Studies 36, no. 2 (Summer 2001): 70-105.

Michael Graydon, " 'Kids Not Rights, is Their Craving': Sex Education, Gay Rights, and the Threat of Gay Teachers," Canadian Review of Sociology 48, no. 3 (August 2011): 313-339.

Provincial Archives of Alberta, Edmonton. Supreme Court of Alberta Criminal Division Records. Accession 83.1. 
Robinson, Daniel J. and David Kimmel. "The Queer Career of Homosexual Security Vetting in Cold War Canada." Canadian Historical Review 75, no. 3 (September 1994): 319-345.

Warner, Michael. The Trouble with Normal: Sex, Politics, and the Ethics of Queer Life. Cambridge, Massachusetts: Harvard University Press, 1999.

Whitaker, Reg, and Gary Marcuse. "Security Screening Civil Servants." In Cold War Canada: The Making of a National Insecurity State, 1945-1957, 161-187. Toronto: University of Toronto Press, 1994. 